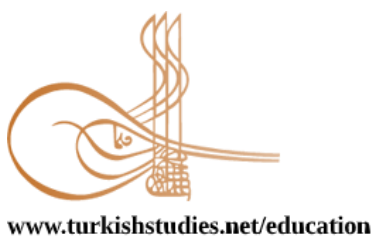

Turkish Studies - Educational Sciences

\title{
Çocuk Gelişimi Okuyan Bireyin Sahip Olmak İstediği Meslek Ve Tercihlerinin Nedenleri İle Beraber İncelenmesi*
}

\author{
Examination of the Individual Who Studying Child Development with the Reasons of Profession \\ and Preferences Which Wants to Have
}

\author{
Salih Gülen**
}

\begin{abstract}
The purpose of this study is to determine the individual's who studying child development, profession that wants to have since childhood and situation for reaching this with reasons. Qualitative research method was used in the study.Homogeneous samples were used in the study with 48 participants. All participants participated in the study voluntarily. The data were analyzed both descriptively and content with category-encoded. As a result of analysis of data; it is determined that the majority of the participants want to be a teacher in the future. It is understood that the majority of the participants have professions in the light of sacred values such as raising future generations and helping people. It can be said that the positive and negative experiences of the participants in their childhood years had an effect on the choice of profession. In general, it was determined that the participants could not win the profession in their dreams because of not getting enough points, family effect or physical characteristics. It is determined that the participants who did not win because of not having enough points in their dream profession, preferred child development program due to reasons such as raising future generations, making unconscious choices and not having future anxiety. In line with the results; Individuals who have completed child development from college must complete a license in order to become a teacher. In addition, the individual has to research the profession who wants to have since childhood. It is recommended that the individual receives expert help in their career preferences and directs them in line with their interests and abilities.
\end{abstract}

StructuredAbstract: The purpose of this study is to determine the individual's who studying child development, profession that wants to have since childhood and situation for reaching this with reasons. For this purpose, the answers to the following questions were sought.

1. Which professions were most imaginable since childhood?

2. What are the reasons for the imagination of imagination since childhood?

3. Have imagined occupations been reached?

4. What are the reasons for choosing a different profession if the imagined profession is not reached?

\footnotetext{
*Bu çalışma 2018-2019 eğitim öğretim sezonunda (Aralık-2018) gönüllü katılımcılar ile yapılmıştır.

*** Dr., Muş Alparslan Üniversitesi, Malazgirt Meslek Yüksekokulu, Çocuk Gelişimi

Dr., University of Muş Alparslan, Malazgirt Vocational School, Child Development

ORCID 0000-0001-5092-0495

sgnova@windowslive.com

Cite as/ Atıf:Gülen, S.(2020). Çocuk gelişimi okuyan bireyin sahip olmak istediği meslek ve tercihlerinin nedenleri ile beraber incelenmesi, $\quad$ TurkishStudies-Education, $\quad 15(3), \quad 1893-1906$. https://dx.doi.org/10.29228/TurkishStudies.41996

Received/Geliş: 04 March/Mart 2020

Accepted/Kabul: 21 June/Haziran 2020

Checked by plagiarism software

Copyright $($ INTAC LTD, Turkey 
Methodology: Qualitative research method was used in the study. This method is used to determine the causes of research questions (Glesne, 2013). In the content analysis conducted to ensure validity of the study, direct quotations were given and the accuracy of the research results was shown. In the reliability study, the situation of the sample group was explained in detail, the existing roles were explained, and the conceptual framework and data collection and analysis were presented. In addition, these data were supported by descriptive analysis (Merriam, 2013).

Participants: Homogeneous samples were used in the study. The aim in the analogous sample is to determine the status of groups with similar characteristics in a subject in order to collect qualitative data effectively (Yıldırım and Şimşek, 2013). As a matter of fact, the research was conducted with the first year students of the Child Development of a university in the Eastern Anatolia Region during the 2018-2019 academic years. Class size was determined to be 48 . It was determined that the participants were from the same region and their socio-economic status was similar.

Data collection tool: A semi-structured interview form was used to obtain data from multiple participants at the same time (Yıldırım and Şimşek, 2013). A semi-structured interview form has the following questions.

1. What would you imagined your profession to be since your childhood? Can you write with reasons?

\section{Why did you preferences Child Development?}

Analysis of data: The semi-structured interview form was analyzed both descriptively and in content. Code and categories were used. Participants are coded with numbers 1 to 48 .

Conclusions and recommendations: As a result of the analysis of all data, it was determined that the majority of the participants wanted to be a teacher to raise future generations. In addition, it was found that the participants who imagined of profession like police, nurse, doctor to help people. Apart from these, it was determined that some participants imagined of different profession with the effect of childhood experiences and role models. In general, the imagination of the teaching profession which is considered sacred is an important result in terms of education. It is very effective for the participants to see the profession as police, nurse and doctor. It should also be noted that all kinds of occupational groups are actually role models for some. Finally, due to the fact that the experiences in childhood affect the career choice, attention should be paid to the lives of the children and the occupational groups in which they interact.

It was determined that the participants could not win the profession they imagined of due to not getting enough points, family effect or physical characteristics. The reason why no participant has won imagines profession is due to the limitation of the research, because this research has been done with the students who choose the profession in child development. However, no data were found that read the imaginary child development program. This shows that the efforts of individuals to achieve the profession that they have targeted since childhood should be followed and necessary support should be given.

It is determined that the participants who do not win because they do not have enough score in their dreams, prefer child development because they want to have a sacred duty like raising future generations. This result is very important. It shows that individual understands child development and the importance of next generation. Furthermore, it was determined in the participants who preferred the child development program for reasons such as unconsciously choosing and not having any future anxiety. In the framework of this result determined in the study, it is suggested that expert assistance should be obtained especially during the process of making university preferences. Indeed, it is clear that they do not understand what the lost years mean. It is also wrong for individuals to choose the profession that has the fastest assignment or the earliest job to avoid future anxiety. In general, such results bring unhappiness, because the individual always has to choose the profession according to his / her interest skills and abilities.

Keywords: Child development, Career, Profession preferences, Teacher, Values

Öz: Bu araştırmanın amacı çocuk gelişimi okuyan bireyin çocukluktan beri sahip olmak istediği mesleği ve bu mesleğe ulaşıp ulaşmadığını nedenleri ile beraber belirlemektir. Çalışmada nitel araştırma yöntemi kullanılmıştır. Araştırmada benzeşik (homojen) örneklem kullanılmıştır. Áraştırma 2018-2019 eğitim öğretim 
sezonunda Doğu Anadolu Bölgesindeki bir Meslek Yüksekokulu Çocuk Gelişimi birinci sınıf öğrencileri ile yapılmıştır. Sınıf mevcudu 48 olduğu belirlenmiştir. Katılımcıların tamamı araştırmaya gönüllü katılmışlardır. Araştırmada birden çok katılımcıdan aynı anda veri elde etmek için yarı yapılandırılmış görüşme formu kullanılmıştır. Veriler kodlanarak hem betimsel hem de içerik olarak analiz edilmiştir. Verilerin analizi sonucu; katılımcıların çoğunluğunun gelecekte öğretmen olmak istedikleri belirlenmiştir. Katılımcıların çoğunluğu gelecek nesilleri yetiştirmek ve insanlara yardım etmek gibi değerler 1şığında meslek tercihlerinde bulundukları anlaşılmaktadır. Katılımcıların çocukluk yıllarındaki olumlu ve olumsuz yaşantılarının meslek tercihine etki ettiği söylenebilir. Genel olarak katılımcıların hayallerindeki mesleği yeteri puan alamama, aile etkisi ya da fiziki özelliklerden dolayı kazanamadığı belirlenmiştir. Hayalindeki mesleği puanı yetmediği için kazanamayan katılımcıların gelecek nesilleri yetiştirmek, bilinçsiz tercihte bulunmak ve gelecek kaygısı yaşamamak gibi nedenlerden dolayı çocuk gelişimi programını tercih ettikleri tespit edilmiştir. Sonuçların paralelinde; yüksekokuldan çocuk gelişimi bölümünü bitiren bireylerin öğretmen olabilmeleri için lisans tamamlamaları gerekmektedir. Ayrıca bireyin çocukluk yıllarından itibaren sahip olmak istediği mesleği iyi araştırması gerekmektedir. Bireyin meslek tercihlerinde uzman yardımı almaları, kendi ilgi ve yetenekleri doğrultusunda yönlendirmeleri önerilmektedir.

Anahtar Kelimeler: Çocuk gelişimi, Kariyer, Meslek tercihi, Öğretmen, Değerler.

\section{Giriş}

Birey hayata gözünü açtığı andan itibaren belli bir kariyer doğrultusunda yetiştirilir. Birey sahip olduğu ilgi ve beceriler doğrultusunda eğitim alır ve mutlu olacağı bir kariyer planlar. Kariyer, bireyin kimliğini, statüsünü, yaşam tarzını ve toplumsal durumunu temsil etmektedir (Yükselen ve ark., 2016). Bireyin kariyer gelişiminde en önemli adım meslek tercihidir. Birey kabiliyeti, becerisi, davranışı, değerleri, güdü ve ihtiyaçları doğrultusunda meslek tercihinde bulunur (Aytaç, 2005). Temelde meslek, kişinin çalışma alanı, geçimini sağladığı iş olarak görülmektedir.

Birey belli bir yaşın olgunluğuyla beraber meslek tercihlerini dile getirir. Önemli olan bireyin meslek seçiminde, hedeflerine ulaşmasına yardım edecek eğitim ortamlarının hazırlanmasıdır. Bu ortamların sanayi ve teknolojik gelişmeler ölçüsünde olması gerekmektedir (Deniz, 2001). Hızla ilerleyen bu gelişmeler bireyin, yıllardır devam eden mesleklerin yanı sıra yeni meslekleri tanımasını sağlamaktadır. Nitekim okullarda meslek eğitimi ve mesleki rehberlik olmak zorundadır (Yarcan, 2007). Bireyin geleceğe yönelik kaygısının azaltılmasında ve yapabileceği seçimlerin kendisini mutlu etmesi açısından bu uygulama büyük önem taşımaktadır. Bireyin meslek seçiminde mesleği tanıması onun gelecek kaygısını azaltacağı bilinmektedir (Narin, Ünver ve Narin, 2018).

Bireyin meslek tercihleri üzerinde birçok unsurun etkili olduğu bilinmektedir. En önemli ve en erken etki eden unsur ailedir. Aile bireyin meslek tercihinde gerek rol model olması gerekse sözel telkinlerle etki etmektedir. Ayrıca bazı ailelerin bireye meslek tanıtımı yaptığı, farklı meslekleri örneklediği ve gelecek nesillerde en popüler olabilecek meslekleri ele aldığ da olmuştur. Sonuçta aile bireyin kariyeri için en önemli mesleği seçmesini arzulamaktadır (İbrahimoğlu, 2017). Bireyin meslek tercihlerini etkileyen bir diğer unsur eğitim ortamıdır. Okul bireyin eğitim aldığı farklı meslekleri tanıma firsatı bulduğu eğitim ortamıdır. Özellikle okullarda yapılan istihdam ve kariyer günleri etkinliklerinin öğrenciler tarafından yeterli düzeyde yönlendirici ve kariyer kararlarını vermede etkili olduğu biliniyor (Aylar, 2012; Eşitti ve Buluk, 2018). Bu tarz faaliyetlerin meslek seçimini kolaylaştırdığı düşünülmektedir. Araştırmacıların verilerine göre okuldaki dersler bile meslek tercihini etkilemektedir (Paolillo ve Estes, 1982). Ayrıca bireylerin hangi mesleğe yönelik ilgilerinin olduğu araştırıldığında, bireyin karar verme ya da mesleği hayal etme durumu kolaylaşmaktadır. Nitekim okulda öğrenilenlerin meslek ilişkileri açıklandığında bireyde mesleğe yönelik tutum oluşmaktadır (Şata ve Çakan, 2018). Bireyin yaşadığı ortamın sosyo kültürel farklılıkları, yörenin coğrafik özellikleri, yörenin ihtiyaç durumları gibi faktörlerde bireyin meslek tercihini etkilemektedir. Meslek seçimini etkileyen bir diğer 
unsurda maddi kazançtır. Bireyin hedef mesleğinin maddi kazancının tatmin edici düzeyde olması gerekmektedir (Yükselen ve ark., 2016). Meslek seçiminde küçüklük yaşlardaki yaşantılarda önemlidir. Bireyin küçüklüğünden beri okuduğu kitaplarda ya da arkadaşlarından edindiği bilgilerden meslekleri öğrendiği bilinmektedir. Ayrıca izlediği televizyon filmleri, diziler veya programlarda bunda etkilidir. Özellikle bireyin toplumda farklılık yaratacak meslekleri bu dönemde düşündükleri söylenebilir. Fakat yılların geçmesi ile bu durum değişmektedir. Nitekim Sadler, Sonnert, Hazari ve Tai (2012) çalışmalarında bireyin özellikle küçük yaştan itibaren fen ve mühendislik alanlarındaki mesleklere ilgi duyduğu ama zamanla bu ilginin azaldığını tespit etmişlerdir.

Genel olarak bireyin meslek tercihini; ailesi, rol modelleri, kültürel değerleri, çocukluk yaşantıları ve maddi kazanç beklentisi etkilemektedir (Aylar, 2012). Bunların dişında meslek seçiminde cinsiyet faktörünün de etkili olduğu gözden kaçırılmamalıdır (Hazari, Sonnert, Sadler ve Shanahan, 2010). Sonuç olarak bireyin seçeceği mesleğin belirlenmesinde birçok unsur etki etse de, birey bu mesleği öz-yeterliliği ve ahlaki değerleri çerçevesinde yapmaktadır (Betz ve Hackett, 1986; Taliyer, 2014).

Türkiye'de de bireyin kariyer planlaması ve meslek tercihinde aynı etmenler etkilidir. Özellikle ülkenin az gelişmiş bölgelerinde meslek tercihi bireyin yetenekleri doğrultusunda kazanca göre düşünülmektedir. Bunda da gelecek kaygısı etki etmektedir. Öncelikli hedef çoğunlukla bir an önce devlet memuru olmaktır. Bunun dışında ülkemizde birçok mesleğin kullanımı hatta tanımı bile yoktur (Pazarçeviren, 2005). Fakat Avrupa Eğitim ve Yetiştirme Stratejisinde 2020'ye göre birçok ülkenin eğitim ve yetişme sistemi reform yapmış, hedefleri yakalamaya yakın olarak görülmektedir. Türkiye'de bilgi ekonomisi için ekonomik reformların sürdürülmesi ve insana yatırım yaparak toplumsal bir Avrupa modeline ağırlık vermektedir (Özmusul, 2012).

Genel olarak Türkiye'de ilk sekiz yıllık eğitim zorunludur ve burada rehberlik faaliyetleri kapsamında meslekler tanıtılır. Bundan sonra bireyler merkezi bir sınav sonuçlar ile ilgi ve yetenekleri doğrultusunda lise tercihinde bulunurlar (Bakırcı ve Kırıcı, 2018). Türkiye'de liseler çeşitli özellikler bakımından farklılık göstermektedirler. Akademik başarının ön planda tutulduğu liseler olduğu gibi ara eleman yetiştiren meslek liseleri de mevcuttur. Lise boyunca meslek tanıtım rehberliği devam eder. Hatta bazı liseler kariyer günleri düzenlemektedir. Lise bitince merkezden yapılan sınavın sonuçlarına göre puan alırlar (Kutlu, 2001). Üniversiteyi kazanma sınavı temel olarak bireyin akademik başarısını ölçmektedir. Bu sınavdan aldıkları puan bireyin üniversiteyi yani hedefindeki mesleği kazanıp kazanamadığını belirler. Nitekim üniversite bireyin sahip olacağı meslek eğitimini verir (Şeker, Çınar ve Özkaya, 2004).

Birey çocukluğundan itibaren sosyal çevre modelleri, aile etkisi veya rehberlik faaliyetleri sonucunda bir meslek sahibi olmayı hayal eder. Bu hayalde birey, kendi yetenek ve ilgi alanları çerçevesinde yapabileceği ve mutlu olacağını düşündüğü bir meslek seçer. Zaman geçtikçe insanların ne kadarının hayalindeki mesleğe ulaşılabildiği merak konusudur. Ayrıca mesleğe ulaşılmama nedenleri ya da farklı bir mesleği tercih etme veya zorunda kalma nedenlerinin neler olduğu belirlenmelidir.

\section{Araștırmanın Amacı}

$\mathrm{Bu}$ araştırmanın amacı çocuk gelişimi okuyan bireyin çocukluktan beri sahip olmak istediği mesleği ve bu mesleğe ulaşıp ulaşmadığını nedenleri ile beraber açıklamaktır. Bu amaç kapsamında aşağıdaki soruların cevapları aranmıştır.

1. Çocukken en çok hangi meslekler hayal edilmektedir?

2. Çocukken hayal edilen mesleklerin hayal edilme nedenleri nelerdir?

3. Hayal edilen mesleklere ulaşılabilinmiş mi? 
4. Hayal edilen mesleğe ulaşılamamışsa, farklı bir mesleği tercih etme nedenleri nelerdir?

\section{Yöntem}

Çalışmada nitel araştırma yöntemi kullanılmıştır. Araştırma sorularının nedenlerini belirlemede bu yöntem kullanılır (Glesne, 2013). Araştırmanın geçerliliğini sağlamada yapılan içerik analizinde direkt alıntılara yer verilerek araştırma sonuçlarının doğruluğu gösterilmiştir. Güvenirlik çalışmasında ise örneklem grubun durumu ayrıntılı belirtilmiş, var olan roller açıklanmış, kavramsal çerçeve ile veri toplamı ve analizi sunulmuştur. Ayrıca bu veriler betimsel analiz ile desteklenmiştir (Yıldırım ve Şimşek, 2013).

\section{Katılımcilar}

Araştırmada benzeşik (homojen) örneklem kullanılmıştır. Benzeşik örneklemdeki amaç nitel verilerin etkili bir şekilde toplanabilmesi için benzer özellikteki grupların bir konudaki durumunun belirlenmesidir (Yıldırım ve Şimşek, 2013). Nitekim araştırma 2018-2019 eğitim öğretim sezonunda Doğu Anadolu Bölgesindeki bir Meslek Yüksek Okulu Çocuk Gelişimi birinci sınıf öğrencileri ile yapılmıştır. Yaklaşık iki saat süren araştırmada 48 katılımcı bulunmaktadır. Katılımcıların 3'ü erkek geri kalanı kadındır. Katılımcıların genelinin aynı bölgeden oldukları ve sosyo ekonomik durumlarının benzer olduğu tespit edilmiştir.

\section{Veri Toplama Aracı}

Birden çok katılımcıdan aynı anda veri elde etmek için yarı yapılandırılmış görüşme formu kullanılmıştır (Merriam, 2013). Yarı yapılandırılmış görüşme formunda aşağıdaki sorular bulunmaktadır.

1. Küçüklüğünüzden beri mesleğinizin ne olmasını isterdiniz? Nedenleri ile yazar mısınız?

2. Neden "Çocuk Gelişimi” programını seçtiniz?

\section{Verilerin Analizi}

Yarı yapılandırılmış görüşme formu verileri kodlanarak hem betimsel hem de içerik olarak analiz edilmiştir. Katılımcılar 1den 48'e kadar numaralar ile kodlanmıştır. Ayrıca iki farklı uzman tarafından ortak kodlamalar yapılmıştır. Puanlamalar \% 95 oranında görüş birliği ile alınmıştır. Nitekim Miles ve Huberman (1994) göre \% 80 ve yukarısı güvenilir olarak kabul edilmiştir (Arık ve Y1lmaz, 2017).

\section{Bulgular}

Yapılan analiz sonucunda elde edilen bulgular araştırma soruları çerçevesinde aşağıda sunulmuştur. Uygulanan yarı yapılandırılmış görüşme formunun incelenmesi ile katılımcıların verdikler cevaplar analiz edilerek Tablo 1'de verilmiştir.

Tablo 1'de bireyin küçüklüğünden beri olmak istediği meslekler görülmektedir. Ayrıca bu tabloda meslek düşüncelerinin nedenleride belirlenmiştir. Buna göre katılımcıların çoğunluğu öğretmen olmak istemektedir. Katılımcılar içerisinde çocukluğundan beri sık sik fikir değişen bireylerde mevcuttur. Ayrıca polis, hemşire, doktor gibi meslek hayalleri de mevcuttur. Buna göre katılımciların \% 47.92'si öğretmen, \%12.50'si değişken, \% 10.42'si polis ve \%29.17'si diğer meslekleri hayal ettikleri görülmektedir. Tablo 1'in en önemli bölümü ile katıllmciların bu meslekleri hayal etme ya da ileride bu mesleklerin sahibi olma sebepleri belirtilmiştir. Katılımcıların meslek seçme nedenleri üç kategoride ele alınmaktadır. Değer yargıları, çocukluk yıllarında yaşanan bazı olumlu veya olumsuz yaşantılar ya da çevresindeki kişi, kurum veya televizyon sayesinde model edinerek mesleği seçmek istedikleri belirlenmiştir. 
Tablo 1: En Çok Tercih Edilmek İstenen Meslekler İstatistiği

\begin{tabular}{|c|c|c|c|c|c|c|}
\hline Sira & Meslek (N:48) & $\begin{array}{l}\text { Frekans } \\
\text { (f) }\end{array}$ & $\begin{array}{l}\text { Yüzde } \\
(\%)\end{array}$ & Neden (N:48) & $\begin{array}{l}\text { Frekans } \\
\text { (f) }\end{array}$ & $\begin{array}{l}\text { Yüzde } \\
(\%)\end{array}$ \\
\hline 1 & Öğretmen & 23 & 47.92 & Değerler & 32 & 66.67 \\
\hline 2 & Değişken & 6 & 12.50 & Çocukluğundaki yaşantılar & 9 & 18.75 \\
\hline 3 & Polis & 5 & 10.42 & Model & 7 & 14.58 \\
\hline 4 & Hemşire & 4 & 8.33 & & & \\
\hline 5 & Doktor & 3 & 6.25 & & & \\
\hline 6 & Avukat & 3 & 6.25 & & & \\
\hline 7 & Mimar & 1 & 2.08 & & & \\
\hline 8 & Paramedik & 1 & 2.08 & & & \\
\hline 9 & Psikolojik danışman & 1 & 2.08 & & & \\
\hline 10 & Sosyal hizmetler & 1 & 2.08 & & & \\
\hline
\end{tabular}

Tablo 1'de yukarıda belirtilenlerin dışında katılımcıların \% 66.67'si değerlerinden, \% 18.75 'i çocukluk yaşantılarından ve \% 14. 58'i Model aldıklarından dolayı bu meslekleri kazanmak istemektedirler.

\section{A) Katılımcıların Meslekleri İsteme Nedenleri} sunulmuştur

$\mathrm{Bu}$ tema altında belirlenen kod ve kategoriler çerçevesinde yapılan içerik analizi aşağıda

Değer yargılarından dolayı meslek isteme

Meslek isteğine yönelik belirtilen değerler içerisinde en çok tekrar edilen ilk iki ifade Tablo 2 'de verilmiştir. Bu tablo kapsamında yapılan analiz aşağıda sunulmuştur

Tablo 2: Meslek İsteğine Yönelik En Çok Belirtilen Değerler

\begin{tabular}{llll}
\hline Değerler (N:32) & $\begin{array}{l}\text { Frekans } \\
(\mathbf{f})\end{array}$ & $\begin{array}{l}\text { Yüzde } \\
(\boldsymbol{\%})\end{array}$ & Katılımcılar \\
\hline Geleceğin nesillerini yetiştirmek & 18 & 56.25 & $\begin{array}{l}\text { K4, K5, K7, K8, K9, K11, K16, K22, K23, } \\
\text { K47 }\end{array}$ \\
\hline İnsanlara yardım etmek & \multirow{2}{*}{14} & 43.75 & $\begin{array}{l}\text { K2, K3, K13, K15, K17, K19, K27, K28, K32, } \\
\text { K37, K40, K43, K44, K45 }\end{array}$ \\
\hline
\end{tabular}

Tablo 2'ye göre değer yargılarından dolayı meslek seçiminde bulunmak isteyen katılımcıların \% 56.25'i geleceğin nesillerini yetiştirmek, \% 43.75' $\mathrm{i}$ ise insanlara yardım etmek gibi değerlere sahiptirler. Katılımcıların gelecekte seçmek istedikleri mesleğe yönelik sahip olduğu değerlerden geleceğin nesillerini yetiştirme isteğine yönelik alıntılar aşağıda verilmiştir:

Küçüklüğümden beri hep ögretmen olmak istiyordum. Nedeni ise kendimi çocukların arasında ve onların o parlak parlak bakan gözleriyle geleceğin nesillerini daha iyi yetiştirmek, onlarla geleceğin temellerini atmak (K4).

Küçüklüğ̈̈mden beri hep ögrretmen olmak istiyordum. Çünkü ögretmenlik kutsal bir meslektir. Değerli çocukları yetiştirmek onların her şeyi ile ilgilenmek eksiklerini görmek örneğin yırtık ayakkabısını görmek ögretmen olmaktır (K16).

En çok ögretmen olmak istedim. Çünkü gelecek nesillere yol veren bir araçtır (K34)

.... Öğrendim ki ilk adımlara sağlam ve kaliteli bir şekilde başlamam lazım ki geri kalan hayatımda anlamlı... Tüm bunları gerçekleştirmek için iyi bir eğitimcinin elinden geçeceğini anladım bu yüzden iyi bir eğitimci yani ögretmen olmak istedim (K46) 
Yukarıdaki alıntılar çocukları "değerli", "geleceğin temelleri" olarak görüldüğü ve onların eğitimlerinin "sağlam" ve "kaliteli" olması gerektiği, bununda anca "eğitimciler" yani "ögretmenler" sayesinde yapılabileceği anlaşılmaktadır. Ayrıca "kutsal" ve "yol veren" bir rehber olarak görülmesi gibi nedenlerden dolayı katılımciların "öğretmen" olmak istedikleri anlaşılmaktadır. Bu alıntılar öğretmenliğin kutsal görülmesi ve gelecek nesilleri yetiştirmesinden dolayı gelecekte edinebilecek bir meslek olarak göstermektedir. Bu ifadelerin dişında meslek tercihinde insanlara yardım etmeyi amaçlayan değerlerinde olduğu aşağıdaki alıntılarda görülmektedir:

Hep parametikçi olmak istemişimdir. Çünkü insanların hayatlarını kurtarmak istiyordum (K2).

Hemşire olmak isterdim. Çünkü hastalara bakmayı ve yardımcı olmayı çok isterdim (K17).

En çok istediğim meslek çocuk doktoruydu. Küçükken hasta çocukları görürken hep çocuk doktoru olmak istedim (K43).

Çocukluğumdan beri hep polis olmak istedim. Yararlı bir şeyler yapmak, insanlara yardim etmek için... (K45).

Yukarıdaki alıntılar "hayat kurtarmak", "hasta bakmayl", "yardımcı olmayı", "hasta çocuklara" bakmayı gibi nedenlerden dolayı "insanlara yardımı" dokunacak meslekler tercih ettikleri anlaşılmaktadır. $\mathrm{Bu}$ alıntılar katılımcıların insanlara yardımı dokunacak meslekleri düşündükleri anlaşılmaktadır. Bunların dışında çocukluk yıllarındaki yaşantılara dayanarak meslek tercihinde bulunan katılımcıların alıntıları aşağıda verilmiştir.

\section{Çocukluk yaşantılardan dolayı meslek isteme}

Bu kategoride edinilen olumlu ve olumsuz yaşantılar üzerinden analiz yapılmaktadır. Tablo 3'te bu duruma yönelik alıntıları belirlenen katılımcıların durumları belirtilmiştir.

Tablo 3: Çocukluk Yaşantılarının Meslek Tercihine Etkisi İstatistiği

\begin{tabular}{llll}
\hline Çocukluk yaşantısı (N: 9) & Frekans (f) & Yüzde (\%) & Katılımcılar \\
\hline Olumlu yaşantılar & 5 & 55.56 & K10, K12, K14, K20, K21 \\
\hline Olumsuz yaşantılar & 4 & 44.44 & K6, K38, K39, K42 \\
\hline
\end{tabular}

Katılımcıların bazıları çocukluk yıllarında edindikleri duygusal yaşantılar sonucu meslek tercihinde bulunmak istedikleri anlaşılmaktadır. Buna göre katılımcıların \% 55.56'sı çocukluk döneminden olumlu yaşantılar ile meslek tercihinde bulunurken \% 44.44'ü olumsuz yaşantılar ile meslek tercihinde bulunmak istediği anlaşılmaktadır. Katılımcıların çocukluk yıllarındaki olumlu yaşantıların meslek tercihlerine etkisi aşağıda sunulmuştur:

Çevremde gördüğ̈̈m meslek öğretmendi, Türkçe öğretmeni ise ilkokuldayken en iyi yaptlğım ders Türkçe olduğu için Türkçe ögretmeni olmak istedim (K10).

...sınıf öğretmeni olmak istiyordum. ...sinıf öğretmenimizin bizimle ilgilenmesi hoşumuza gidiyordu... (K14).

...yurt belletmen hocam okul öncesi öğretmeniydi. Bize okulu, çocuklarl, çocuklara sevgi göstermemiz gerektiğini, onları toplum için iyi yetiştirmemiz gerektiği ve bunun sabrı ögrettiğ $i$ gibi sebepler... (K20).

Folklor hocası (ögrretmeni) olmak isterdim, çünkü halk oyunları konusunda oldukça yetenekliyim. Tüm yörelerin oyunlarını kendi başıma öğrenebildim... (K21).

Yukarıdaki alıntılar, katılımcıların çocukluk yıllarında başarılı oldukları "ders", öğretmenlerinin "ilgisi", "çocukları" ve çocukların "toplum" için öneminin kavratması ve 
"yetenekleri" gibi unsurlardan dolayı meslek seçiminde bulunmak istedikleri anlaşılmaktadır. Bu ifadelerin dışında tespit edilen olumsuz ifadelerde aşağıda sunulmuştur:

...küçüklüğ̈̈̈mdeki dişlanmam, peltek konuşmamadan dolayı sözümün pek dinlenmemesi, bulunduğum yerin baskısı gibi nedenlerden dolayı hiç dinlenilmedim. Bu yüzden iyi bir dinleyici olup sorunlara çözüm üretmek için psikolojik danışman olmak istiyorum ...(K6).

...küçüklüğümde iyi bir eğitim almadım. Öğretmenim hep beden eğitimi dersi yaptıriyordu. Öğrenciler 2 saat çallşırken ben 4 saat çalışırdım anca anlardım. Bu yüzden iyi bir eğitim veren ögretmen olmak isterdim (K38).

...ögretmen olmak isterdim ama ülke şartları ve atama sorunu bu mesleği hayal etmemi engellerdi. Voleybolcu olmak isterdim ama kızların bu sporu seçmesi uygun görülmüyordu... (K39).

...ögretmen dişarı çıkmıştı sinufta top oynayan çocuklar öğretmen masasındaki öğretmen gözlüğ̈̈nü kirdl, öğretmene benim kirdiğımı söylediler. Öğretmen beni sinıftan kovdu ... beni sinıftaki oyundan mahrum biraktı... bu nedenle çocukları oyunlarından mahrum birakmamak için ögretmen olmak istiyorum... (K42).

Katılımcıların çocukken "yeterli" eğitim alamaması, ders işlemeleri gerekirden vakitlerinin "dışarıda" geçmesi, "ülke şartları ve atanma", öğretmeninin onu haksız yere sınıftan "kovması" ve oyundan "mahrum" etmesi ve fiziksel özrü nedeni ile kimsenin kendisini "dinlememesi", "dlşlanması" gibi nedenlerden dolayı meslek tercihleri yapmak istedikleri anlaşılmaktadır. Katılımcılar psikolojik destek alamadıkları için "psikolojik danışman", iyi eğitim alamadı için ve çocukların oyunlardan "mahrum" kalması gibi nedenden dolayı "öğretmen" ve bayanlara toplumsal bakıştan dolayı meslek seçimleri şekil kazanmıştır. Bunların dışında katılımcılardan bazıları edindikleri modellerden dolayı meslek tercihinde bulunmak istemişlerdir.

\section{Edindiği modellerden dolayı meslek isteme}

Katılımcıların çevresinden edindiği modellerin meslek tercihine etkisine ait istatistik tablo 4'te verilmiştir.

Tablo 4: Çevresinden Edindiği Modellerden Dolayı Meslek İsteme İstatistiği

\begin{tabular}{llll} 
Çocukluk yaşantısı (N:7) & Frekans & Yüzde (\%) & Katılımcılar \\
\hline Çevresinden model alma & 7 & 100 & $\begin{array}{l}\text { K1, K24, K25, K27, K32, K35, } \\
\text { K40 }\end{array}$ \\
\hline
\end{tabular}

Tablo 4'te model edinen katılımcılar gösterilmektedir. Tabloya göre katılımcıların tamamı çevresinden model edinmiştir. Bu katılımcılardan bazılarının alıntıları aşağıda verilmiştir:

...babamın avukat arkadaşı bize gelirdi. Konuşması, hak ve adalet arayışı beni çok etkilerdi... cübbeyi giymek isterdim... (K1).

...ögrretmen olmak isterdim. Öğretmenlerime çok özenirdim onlar gibi değer ve saygı görmek isterdim (K24).

...hemşire olmak isterdim. Çünkü bizim oralarda doktor-hemşire olan okumuş büyük insan olmuş demekti... (K27).

...polis olmak isterdim. Çünkü amcam polis yaptı̆̆ından dolayı hep sevmişimdir... (K35).

Alıntılardan anlaşıldığı gibi "konuşması", "hak ve adalet arayıı̧ı" gibi nedenlerden babasını arkadaşı olan "avukat", "değervesaygıdan" dolayı "ögretmen", "büyük insan" görülmesinden dolay1 "hemşire" ve amcasının "polis" olmasından dolayı katılımcılar bu meslekleri tercih etmek istemişlerdir. Alıntılardan da anlaşılacağ 1 gibi çevredeki meslek sahiplerinin davranışları veya bu mesleğe toplumun verdiği değer yargıları gibi nedenlerden dolayı katılımcıların model edindikleri anlaşılmaktadır. Fakat her ne kadar yukarıda belirtilen meslekler tercih edilmek istense de hiçbir 
katılımcının kendi mesleğini kazanamadığ 1 veya seçemediği anlaşılmaktadır. Bu durumun araştırılması ile elde edilen bulgular aşağıdaki tema altında sunulmuştur.

\section{B) Katılımcıların hayalindeki mesleği tercih etmeme nedenleri} sunulmaktadir.

$\mathrm{Bu}$ tema altında katılımcıların neden çocuk gelişimi seçtiklerine yönelik veriler

Tablo 5: Katılımcıların Çocuk Gelişimi Programı Tercih Etme Nedenleri İstatistiği

\begin{tabular}{llllll}
\hline Tercih edilen meslek (N:48) & Frekans (f) & Yüzde (\%) & Nedeni (N:48) & Frekans (f) & Yüzde (\%) \\
\hline \multirow{3}{*}{ Çocuk gelişimi } & \multirow{2}{*}{48} & Yetersiz puan & 43 & 89.58 \\
\cline { 4 - 6 } & \multirow{2}{*}{100} & Aile isteği & 3 & 6.25 \\
\cline { 3 - 5 } & & Fiziksel şartlar & 2 & 4.17 \\
\hline
\end{tabular}

Tablo 5'te görüldüğü gibi katılımcıların istedikleri mesleği değil de, üniversiteye yerleşme puanı, aile isteği ve fiziksel nedenlerden dolayı başka bir mesleği tercih ettikleri görülmektedir. Bu katılımcıların üç tanesi ailesinin baskısı veya kendisine haber vermemesinden dolayı (\% 6.25), iki tanesi de polislik şartlarındaki fiziksel özellikleri sağlamadıkları (\% 4.17) için çocuk gelişimini istemeden de olsa seçtikleri belirlenmiş̧ir. Bunun dışında katılımcıların büyük çoğunluğunun (\% 89.58) puanları yetmediği için çocuk gelişimini tercih ettikleri belirlenmiştir. Burada araştırılması gereken istedikleri mesleğe puanlarının yetmemesinden dolayı daha farklı bir meslek tercih edebilirken neden çocuk gelişimi tercih edildiğidir. Bu durum aşağıda ayrıntılı olarak analiz edilmiştir.

\section{C) Neden çocuk gelişimi?}

Katılımcıların çoğunluğu öğretmenlik mesleği olsa da farklı farklı meslekler yapmak istedikleri belirlenmişti fakat katılımcıların büyük çoğunluğu bu meslekleri kazanmak için yeteri puan alamadıkları bu nedenle çocuk gelişimi programını seçtikleri tespit edilmiştir (Tablo 5). Fakat burada katılımcıların çocuk gelişimi dışında daha farklı programları da seçebilecekleri bilinmektedir. İşte bu yüzden özellikle çocuk gelişimini neden seçtikleri araştırılmıştır. Bu kapsamda aşağıda verilen kategoriler altında katılımcıların alıntıları analiz edilmiştir.

Hayalindeki mesleğe puanı yetmeyen katılımcıların çocuk gelişimi seçme nedenleri Tablo 6'da verilmiştir.

Tablo 6: Puanı Yetmeyen Katılımcıların Çocuk Gelişimini Tercih Etme İstatistiği

\begin{tabular}{llll}
\hline Nedenler (N: 43) & Frekans (f) & Yüzde (\%) & Katılımcılar \\
\hline $\begin{array}{l}\text { Gelecek nesilleri } \\
\text { yetiştirmek }\end{array}$ & \multirow{2}{*}{25} & K8.14 & $\begin{array}{l}\text { K22, K24, K8, K25, K11, K14, K16, K18, K19, K20, K21, } \\
\text { K42, K43, K46, K48, K30, K31, K34, K36, K38, K41, }\end{array}$ \\
\hline $\begin{array}{l}\text { Bilinçsizce } \\
\text { tercihte bulunma }\end{array}$ & 13 & \multirow{2}{*}{30.23} & $\begin{array}{l}\text { K2, K5, K6, K7, K12, K17, K23, K29, K33, K37, K40, } \\
\text { K44, K47 }\end{array}$ \\
\hline $\begin{array}{l}\text { Gelecek kaygis1 } \\
5\end{array}$ & 11.63 & K10, K15, K27, K35, K39 \\
\hline
\end{tabular}

Tablo 6'da görüldüğü gibi 25 katılımcı (\% 58.14) gelecek nesilleri yetiştirmek, 13’ü (\% 30.23) bilinçsizce yapılan tercih sonucu ve 5 tanesi (\% 11.63) de gelecekte iş kaygısı yaşamamak için tercihte bulunmuştur. Bu kategorilere yönelik alıntılar aşağıda sunulmuştur:

\section{Gelecek nesilleri yetiştirmek}

$\mathrm{Bu}$ kategori altında hayalindeki mesleği kazanamayan ama çocuk yetiştirmeye yönelik duygularından dolayı çocuk gelişimi programını tercih eden katılımcıların alıntıları verilmiştir:

...zaman geçtikçe çocuklara karşı tutumlarım, onların o bakış açılarında bakmayı öğrendim... Çocuklar bizim mucizemiz onların bakış açısıyla baktı̆̆ımız zaman onları mutlu etmeme gibi bir durumum yok (K1). 
Çocukları sevdiğim için bu bölümü seçtim. Çocuklarla ĕglenmek, mutlu olmak, çocukla çocuk olmak için bu bölümü seçtim. Çocuklara bir şeyler kazandırmak için bu bölümü seçtim (K14).

... Çocukları oyun hamuruna benzetirim. Çocuğa hangi şekli verirsen onu alır... (K19).

Çocuklara iyi şeyler ögrretmek istiyorum, bir bayan olarak bu bölümü okumak güzel geleceğin annesi olarak çocuklarımı iyi yetiştiririm (K24).

Gelecek nesle yol veren ve düzgün bir ahlak verdiği için (K34).

Lise okurken çocuk gelişimi bölümü okumamın etkisi var. Ve ben çocukları çok severim... (K41).

Kendi yaşıtlarımdan çok çocuklara zaman ayırırım. Eve gelen misafirlerin çocukları ile çocuk gibi oynarım... (K43).

Alıntılardan anlaşıldığı gibi çocukların "mucize" olarak görülmesi, onlara bir şeyler "kazandırmak", çocuğun "oyun hamuruna" benzetilerek şekil verilmek istenmesi, lise eğitiminde “aynı bölümü” okuması ve gelecek nesilleri yetiştirmenin düzgün "ahlak" verilmesi gibi nedenlerden dolayı bu bölümün tercih edildiği anlaşılmaktadır. Ayrıca katılımcıların tümünde çocuklara yönelik "sevgi” duygusunun da bu tercihte etkili olduğu düşünülmektedir. Genel olarak katılımcıların çocuklara yönelik sevgi ve ilgilerinden dolayı gelecek nesilleri yetiştirmek istedikleri bu yüzden de çocuk gelişimi bölümünü tercih ettikleri söylenebilir. Yukarıda belirtilen nedenlerin dışında bu bölümü bilinçsizce seçen katılımcıların olduğu da belirlenmiştir.

\section{Bilinçsizce tercihte bulunma}

Hayalindeki mesleği kazanamayan, puanı yetmeyen katılımcıların bazıları çocuk gelişimi bölümünü farkına bile varmadan bilinçsizce tercih etmişlerdir. Bu katılımcılara yönelik alıntılar aşağıda verilmiştir:
Aslında çocuk gelişimi hiç hayal etmedim... Illk seneden üniversiteye gitmek istedim. O yüzden bu bölümü yazdım... (K5).
... Liseyi bilinçsizce seçtim. Lise bitince de hayalimdeki bölüme puanım yetmeyince rastgele tercih yaptım... (K7).
Çocuk gelişimi aklımda bile yoktu. İlk tercihlerim değildi. Nasip herhalde... (K17).
Tamamen nasip, aklımın ucundan bile geçmezdi fakat birde baktım ki buradayım (K29).
Aslında hedefim çocuk gelişimi değildi son tercihte geldi. Gelmeyi düşünmedim. Kader kısmet diyelim... (K37).
Çocuk gelişimi tamamen tesadüfü, Çünkü çocuk gelişimi ile ilgili bir hayalim ya da hedefim yoktu (K40).

Tercihleri ben yapmadım... (K44).

Yukarıdaki alıntılar göstermektedir ki katılımcıların "ilk yıldan" üniversiteye gitme isteği, yanlış "lise" seçimi sonucun da yetersiz puan alması, "gelmez" düşüncesine göre tercih edilmesi, "tesadüfü" ve "hayallerinde" bile olmayan bu programı kazanmalarını "nasip" ya da "klsmet" diyerek kabullendikleri anlaşılmaktadır. Alıntılardan da anlaşıldığ gibi katılımcıların çeşitli nedenle farkına bile varmadan bilinçsizce çocuk gelişimi bölümünü tercih ettikleri ve bunu kader olarak gördükleri söylenebilir. Bu alıntıların dışında katılımcıların bazılarının gelecekte iş bulma kaygısı yaşamamak için çocuk gelişimi bölümünü tercih ettikleri tespit edilmiştir.

\section{Gelecek kaygisı}

Artan işsizlik ve gelecekte iş bulamama gibi nedenlerden dolayı katılımcıların bazıları programı bitirdiğinde iş bulma imkânı en yüksek olan programlardan biri olan çocuk gelişiminini tercih ettikleri anlaşılmaktadır. Bu duruma yönelik alıntılar aşağıda verilmiştir: 
...adalet bölümünü seçmek istiyordum ama çevremdekiler önünün açık olduğunu söylemeleri nedeni ile seçtim... (K10).

Çocuk gelişimi bölümünü seçmemin nedeni önü açık ve puanımla eşdeğer olması ... (K15).

...polis olamasam bile önü açık olduğu için bu meslekte mutlu olacă̆ımı düşündüm (K35).

...önü açık olduğu için bazı bölümlere göre... (K39).

Katılımcıların hayallerindeki bölümü kazanamasalar bile "mutlu" olabilecekleri ve "önü açık" olan bu programı seçip gelecekte iş bulma imkânından faydalanmak istedikleri anlaşılmaktadır. Genel olarak bu katılımcıların gelecekte iş bulma kaygısı yaşamamak için çocuk gelişimi programını tercih ettikleri anlaşılmaktadır.

\section{Tartışma}

Elde edilen verilere göre katılımcıların \% 47.92'si öğretmen, \% 12.50'si değişken, \% 10.42 'si polis ve \% 29.17'si diğer meslekleri hayal ettikleri görülmektedir. Katılımciların bu meslekleri seçme nedenleri üç kategoride ele alınmaktadır. Buna göre katılımcılar değer yargıları, çocukluk yıllarında yaşanan bazı olumlu veya olumsuz yaşantılar ve çevresindeki kişi, kurum veya televizyon sayesinde model edinerek mesleği seçmek istedikleri belirlenmiştir. Buna göre katılımcıların \% 66.67'si değerlerinden, \% 18.75'i çocukluk yaşantılarından ve \% 14. 58'i model aldıklarından dolayı bu meslekleri kazanmak istemektedirler. Katılımcıların öğretmenlik mesleğini kutsal görmeleri, gelecek nesillerin yetiştirilmesinin önemi ve insanlara yardımı dokunacak meslekleri düşünmeleri gibi değer yargıları ile meslek hayali kurdukları söylenebilir. Göktaș ve Taha (2018) öğrencilerin kişilik özellikleriyle kariyer değerleri arasında anlamlı bir ilişkinin olduğunu keşfetmişlerdir. Bu katılımcıların kendi değerlerinin kutsallığını meslek hayallerine yansıttıkları söylenebilir. Katılımcıların çocukluk yıllarında başarılı oldukları ders, öğretmenlerinin ilgisi ve çocukların toplum için önemini gibi unsurlardan dolayı meslek seçiminde bulunmak istedikleri anlaşılmaktadır. Ayrıca katılımcılar çocukluk yıllarında psikolojik destek alamadıkları için psikolojik danışman, iyi eğitim alamadıkları ve çocukların oyunlardan mahrum kalmaması ve bayanlara toplumsal bakıştan dolayı gibi nedenden meslek hayalleri kurmuşlardır. Katılımcıların çocukluk yıllarındaki olumlu ve olumsuz yaşantılarının meslek tercihine etki ettiği söylenebilir. Ayrıca katılımcıların çevredeki meslek sahiplerinin davranışları veya bu mesleğe toplumun verdiği değer yargıları gibi nedenlerden dolayı edindikleri modellere bağlı olarak meslek hayali yapmışlardır. Benzer şekilde Durak ve Avanoğlu (2011) çalışmalarında meslek tercihinde uygulama olanağı, çocuklarla çalışma ve manevi doyum beklentisi gibi yüksek nedenler belirlemiştir. Ayrıca yazar kendi beceri ve yeteneklerine uygunluk / kullanabilme gibi orta düzeyde nedenler ve akademik beklenti ve rol model alınan bir eğitici gibi zayıf nedenler belirlemiştir. Aylar (2012) öğrencilerin yakın çevrelerine dair yaptıkları gözlemler, kendilerine model aldıkları kişiler gibi sosyo-kültürel faktörlerin meslek tercihini etkilediği belirlemiştir. İbrahimoğlu (2017) çalışmasında meslek tercihlerinde temel belirleyici unsurların aile ve rol model alınan birey/meslek olduğunu belirlemiştir. Bu çalışmaların dışında Tanhan ve Yılmaz (2017) öğrencilerin kariyer seçimi kararlarında etkili olan faktörleri ailenin hayalindeki meslek, ailenin eğitim düzeyi, sosyal medya ve anne-babanın mesleği olarak belirlemişlerdir.

Hiçbir katılımcı hayal ettiği mesleğini kazanamadığı veya seçemediği anlaşılmaktadır. Katılımcıların istedikleri mesleği değil de, üniversiteye yerleşme puanı, aile isteği ve fiziksel nedenlerden dolayı başka bir mesleği tercih ettikleri söylenebilir. Bu katılımcıların üç tanesi ailesinin baskısı veya kendisine haber vermemesinden dolayı (\% 6.25), iki tanesi de polislik şartlarındaki fiziksel özellikleri sağlamadıkları (\% 4.17) için çocuk gelişimini istemeden de olsa seçtikleri belirlenmiştir. Bunun dışında katılımcıların büyük çoğunluğunun (\%89.58) puanları yetmediği için çocuk gelişimini tercih ettikleri belirlenmiştir. Benzer şekilde Wen (2018) başka ülkelerde de öğrencilerin sınavlardan geçiş oranının düşük olduğunu belirlemiştir. Ayrıca Çevik (2018) çalışmasında öğrencinin mesleki tercihlerinde birçok etmenin etki ettiğini belirlemiştir. 
Yani meslek seçiminde rol modeller, öğretmen ilgisi, hedefler, çocuklara bakış açısı ve maddi kazanç gibi unsurların etki edebilmektedir.

Hayalindeki mesleğe puanı yetmeyen katılımcıların neden çocuk gelişimini tercih ettikleri incelendiğinde, katılımcıların çoğunluğu çocuklara yönelik sevgi ve ilgilerinden dolayı gelecek nesilleri yetiştirmek istedikleri bu yüzden de çocuk gelişimi bölümünü tercih ettikleri söylenebilir. Bazı katılımcıların ise hemen üniversiteye gitmek istemesi, yanlış tercih yapması gibi nedenlerle farkına bile varmadan bilinçsizce çocuk gelişimi bölümünü tercih ettikleri ve bunu kader olarak gördükleri söylenebilir. Bunların dışında birkaç katılımcı gelecekte iş bulma kaygısı yaşamamak için çocuk gelişimi bölümünü tercih ettikleri tespit edilmiştir. Benzer şekilde İbrahimoğlu (2017) çalışmasında katılımcıların genellikle farklı bölüm/branşı kazanmak istedikleri ancak üniversiteye giriş sınav puanlarının yetersiz kalmasından dolayı puanlarına en uygun bölümü tercih ettiklerini tespit etmiş̧ir. Ayrıca çalışmada katılımcıların bilinçsizce tercihte bulunması bulgusu önem arz etmektedir. Nitekim bu öğrencilerin okul eğitimleri sırasında bu konuda rehberlik yapılmadığ 1 anlaşılmaktadır. Eşitti ve Buluk (2018) okullarda düzenlenen istihdam ve kariyer günlerinin, öğrencilerin kariyerlerini planlamalarında yeterli bir farkındalık oluşturduğunu belirlemişlerdir. Ayrıca Yeşil ve Arpat (2018) meslek tercihinde rehberlik alan öğrencilerin bir yol haritası gerektiğinin bilincindedirler. Bunların dışında Narin, Ünver ve Narin (2018) çalışmalarında seçtiği mesleği tanıyan öğrencinin mezuniyet sonrası iş bulma konusunda endişe duymadığını belirlemişlerdir. İş bulma veya gelecek kaygısı yaşayan öğrencilerin aslında meslekleri tanımadıkları söylenebilir. Bu yüzden öğrencilere eğitimleri süresince meslek eğitimi rehberlikleri veya kariyer planlama günlerinin düzenlenmesi gerekmektedir (Kayri, Elkonca, Şevgin ve Ceyhan, 2014; Sadler, Sonnert, Hazari ve Tai, 2012).

\section{Sonuç ve Öneriler}

Tüm verilerin analizi sonucunda katılımcıların çoğunluğu gelecek nesilleri yetiştirmek için öğretmen olmak istedikleri belirlenmiştir. Ayrıca insanlara yardım etmek için polis, hemşire, doktor gibi meslek hayalleri kuran katılımcılarda olduğu tespit edilmiştir. Bunların dışında katılımcıların bazılarında çocukluk yaşantılarının ve rol modellerinin etkisi ile değişik meslek hayalleri kurdukları tespit edilmiştir. Genel olarak kutsal kabul edilen öğretmenlik mesleğinin çoğunlukla hayal edilmesinin eğitim öğretim açısından önemli bir sonuçtur. Katılımcıların polis, hemşire, doktor gibi meslekleri insanlara yardım eden meslek grupları olarak görmeleri oldukça etkilidir. Ayrıca çevredeki her türlü meslek gruplarının aslında bazıları için birer rol modeli olduğu unutulmamalıdır. Son olarak çocukluk yıllarındaki yaşantıların meslek tercihini etkilemesi nedeni ile bu dönemde çocukların yaşantılarına ve etkileşime girdikleri meslek gruplarına dikkat edilmelidir.

Katılımcıların hayallerindeki mesleği yeteri puan alamama, aile etkisi ya da fiziki özelliklerden dolayı kazanamadığı belirlenmiştir. Hiçbir katılımcının hayalindeki mesleği kazanamama nedeni araştırmanın sınırlılığından kaynaklanmaktadır. Çünkü bu araştırma meslek tercihini yapan öğrencilerle yapılmıştır. Fakat meslek hayali çocuk gelişimi programı okumak olan herhangi bir veriye rastlanmamıştır. Bu da bireylerin çocukluktan itibaren hedefledikleri meslekleri kazanma yolundaki çalışmalarının takip edilmesi ve gerekli desteğin verilmesi gerektiğini göstermektedir.

Hayalindeki mesleği puanı yetmediği için kazanamayan katılımcıların gelecek nesilleri yetiştirmek gibi kutsal bir görevi edinmek istedikleri için çocuk gelişimini tercih ettikleri belirlenmiştir. Bu sonuç oldukça önemlidir. Bireyin çocuk gelişimini ve gelecek neslin önemini kavradığını göstermektedir. Ayrıca bilinçsizce tercihte bulunmak ve gelecek kaygısı yaşamamak gibi nedenlerden dolayı çocuk gelişimi programını tercih eden katılımcılarda tespit edilmiştir. Araştırmada belirlenen bu sonuç çerçevesinde özellikle üniversite tercihlerinin yapılacağ süreçte uzman yardımı alınması gerektiğini göstermektedir. Nitekim kaybolan yılların ne anlam getirdiğini anlamadıkları aşikârdır. Ayrıca bireylerin gelecek kaygısı yaşamamak için en hızlı atamanın olduğu

Turkish Studies -Education, 15(3) 
ya da en erken iş bulunacak mesleği tercih etmeleri de yanlıştır. Genelde böyle sonuçlar mutsuzluk getirmektedir. Çünkü bireyin her zaman kendi ilgi beceri ve yetenekleri ölçüsünde meslek tercihinde bulunması gerekmektedir.

\section{Kaynakça}

Arık, S., \& Yılmaz, M. (2017). Fen bilimleri öğretmen adaylarının çevre sorunlarına yönelik tutumları ve çevre kirliliğine yönelik metaforik algıları. Kastamonu Eğitim Dergisi, 25(3), 1147-1164.

Aylar, E. (2012). Bir vaka çalışması: sosyo-kültürel teori bağlamında gelecekteki hedefler ve özdenetim. Kastamonu Eğitim Dergisi, 20 (3), 767-782.

Aytaç, S. (2005). Çalışma yaşamında kariyer yönetimi planlamasının gelişimi ve sorunları. Ezgi Kitabevi.

Bakırcı, H. ve Kırıcı, M.G. (2018). Fen bilimleri öğretmenlerinin ilköğretimden ortaöğretime geçiş sınavının kaldırılmasına ilişkin görüşleri. Yüzüncü Yıl Üniversitesi Eğitim Fakültesi Dergisi, 15, 383-416.

Betz, N. E., \& Hackett, G. (1986). Applications of self-efficacy theory to understanding career choice behavior. Journal of Social and Clinical Psychology: 4, Special Issue: 279-289. https://doi.org/10.1521/jscp.1986.4.3.279

Çevik, M. (2018). Impacts of the project based (PBL) science, technology, engineering and mathematics (STEM) education on academic achievement and career interests of vocational high school students. Pegem Journal of Education and Training, 8(2), 281-306, http://dx.doi.org/10.14527/pegegog.2018.012

Deniz, S. (2001). Sources that affect the individual's choice of profession: Internet from new technologies. Journal of Social Sciences and Humanities Studies, 6, 1-9.

Durak, H. İ., \&Avanoğlu, A. (2011). Factors influencing the choice of pediatric surgery as a medical career among Turkish pediatric surgeons and residents. Journal of Medical Sciences, 31(2), 450-454.10.5336/medsci.2010-17940

Eşitti, B., \&Buluk, B. (2018). The role of career day's activities in the future of students: a research on tourism management and guidance undergraduate students. Journal of Travel and Hospitality Management 15(1), 38-56.

Glesne, C. (2013). Nitel araştırmaya giriş (Trans. Ed .: Ersoy, A., \&Yalcinoglu, P.). Anıyayıncılık.

Göktaş, P., \& Taha, M. M. (2018). Irak ulusal lisansüstü öğrencilerinin kariyer değerleri ve kişilikleri üzerine bir araştırma. Süleyman Demirel Üniversitesi Sosyal Bilimler Enstitüsü Dergisi, 1(30), 104-137.

Hazari, Z., Sonnert, G., Sadler, P. M., \& Shanahan, M. C. (2010). Connecting high school physics experiences, outcome expectations, physics identity, and physics career choice: A gender study. Journal of Research in Science Teaching, 47(8), 978-1003. https://doi.org/10.1002/tea.20363

İbrahimoğlu, Z. (2017). Sosyal bilgiler ögrretmeni olmak: Nedenvenastl. International Teacher Education and Accreditation Congress, 19-21 May1s.

Kayri, M., Elkonca, F., Şevgin, H., \& Ceyhan, G. (2014). CHAID analysis of the attitudes of secondary school students towards science and technology course. Journal of Educational Sciences Research, 4(1), 301-316. http://dx.doi.org/10.12973/jesr.2014.41.15 
Kutlu, Ö. (2001). Adolescent anxiety caused by university entrance examinations. Education and Science, 26(121), 12-23.

Merriam, S. B. (2013). A guide for qualitative research design and implementation (Trans. Ed.: Turan, S.). Nobel Publishing.

Miles, B. M., \& Huberman, A. M. (1994). Qualitative data analysis (2nd ed.). Sage Publication.

Narin, S., Ünver, B., Narin, A. (2018). Physiotherapy students' expectations and career choice in Turkey. Journal of Exercise Therapy and Rehabilitation, 5(1), 38-45.

Özmusul, M. (2012). Education and training 2020 strategy: Position of the Countries According to The Benchmarks. Journal of European Education, 2(1), 14-27.

Paolillo, J. G. P., \& Estes, R. W. (1982). An empirical analysis of career choice factor among accountants, attorneys, engineers and physicians. The Accounting Review, 57(4), 785-793.

Pazarçeviren, S. Y. (2005). Adli muhasebe. Zonguldak Karaelmas Üniversitesi Sosyal Bilimler Dergisi, 1(2), 1-19.

Sadler, P. M., Sonnert, G., Hazari, Z., \& Tai, R. (2012). Stability and volatility of STEM career interest in high school: A gender study. Science education, 96(3), 411-427. https://doi.org/10.1002/sce.21007

Şata, M., \& Çakan, M. (2018). CHAID analizi ve lojistik regresyon analizi sonuçlarının karş1laştırılması. Ziya Gökalp Eğitim Fakültesi Dergisi, 33, 4856.http://dx.doi.org/10.14582/DUZGEF.1876

Şeker, R., Çınar, D., \& Özkaya, A. (2004). Çevresel faktörlerin üniversite öğrencilerinin başarı oranina etkisi. XIII. National Congress of Educational Sciences, 6-9 July Malatya, Turkey.

Taliyer, M. (2014).Work ethic and engineering. Journal of Business Ethics, 7(1), 175-179.

Tanhan, F., \&Yilmaz, Ü. (2017). Examination of the effects of family and social media on career choice of students (a focus group study). The Journal of Social Sciences Institute, 35, 145157.

Wen, L. (2018). Public accounting and private accounting, career choice of accounting students in China. Journal of Accounting in Emerging Economies, 8(1), 124-140. https://doi.org/10.1108/JAEE-09-2016-0080

Yarcan, Ş. (2007). A conceptual evaluation of code of ethics for professional tourist guides. Anatolia: Journal of Tourism Research, 18(1), 33-44.

Yeşil, Y., \&Arpat, B. (2018). Analyzing opinions about carrier planning of occupational health and safety training students': A research at Pamukkale University. Gümüşhane University Electronic Journal of the Institute of Social Sciences, 9(22), 122-142.

Yildirim, A., \& Simsek, H. (2013). Sosyal bilimlerde nitel araştırma yöntemleri. Seçkin Publishing.

Yükselen, A., Savc1, F., Benan Ozan, G., Baysan, M, Öztürk, S., Yıldırım, E., Kocatürk, A., Şerbetçioğlu, M. (2016). Research on relationship between work values and career choice of first-year college students. Hacettepe Üniversitesi Sağllk Bilimleri Fakültesi Dergisi, 3(1), 169-192. 